\title{
Testing mean-reversion in agricultural commodity prices: Evidence from wavelet analysis
}

\author{
Adedoyin Isola Lawal \\ Dept. of Accounting and Finance, Landmark University, \\ Omu Aran, Nigeria \\ lawal.adedoyin@lmu.edu.ng \\ ORCID: 0000-0001-8295-1560 \\ Oluwasola Emmanuel Omoju \\ National Institute for Legislative and Democratic Studies, \\ Abuja, Nigeria \\ solaomoju@gmail.com
}

\author{
Abiola Ayopo Babajide \\ Dept. of Banking and Finance, \\ Covenant University, Nigeria \\ babajide.abiola@covenantuniversity.edu.ng
}

\author{
Abiola John Asaleye \\ Dept. of Economics, Landmark University, \\ Omu Aran, Nigeria \\ Asaleye.abiola@lmu.edu.ng
}

Abstract. This study examines the validity of the random walk hypothesis for some selected soft agricultural commodity prices within the context of heterogeneous market hypothesis and mean reversion hypothesis. The study employs a battery of traditional unit root tests, GARCH-based models and a novel frequency-based wavelet analysis to analyze daily data sourced from 6th of Jan 1986 to 29th Dec 2018. Contrary to other existing studies that employed only traditional time domain unit root tests, our results reveal that soft commodity prices are mean reverting, suggesting the existence of potential excess returns for investors. Overall, our results show that the selected soft commodity series are inefficient when we factored in heteroscedascity and frequency domain into our model. Our study is an improvement on the existing studies as we analyze our data using both time and frequency domain estimates. Besides, unlike other studies that did not offer structural breaks, the current study provides structural break dates with major events in the global socioeconomic space, which are key to identifying the date of bubbles and potential signs of commodity price bubbles. Our findings have some critical implications for investors, policy makers,

Received:

January, 2019

1st Revision:

May, 2019

Accepted:

November, 2019

DOI:

$10.14254 / 2071$ $8330.2019 / 12-4 / 7$ 
academics and other interested economic agents.

Keywords: wavelet analysis, testing, policy makers.

JEL Classification: J180, P5, D630, I38

\section{INTRODUCTION}

The unit root behavior of agricultural commodity prices is fast attracting the attention of various economic agents, especially market practitioners and policy makers. This stems from the fact that if there is evidence to show that agricultural commodity prices are non-stationary, chances are that any shock to agricultural commodities will be transmitted to other macroeconomic fundamentals. In other words, agricultural commodity prices follow a random walk procedure. This implies a huge potential for absorbing non-stationary property of agricultural commodity prices by other macroeconomic aggregates (Giampietro, Guidolin, \& Pedio, 2018; Jawad, Shahzad, Hernandez, Al-yahyaee, \& Jammazi, 2018; Ulusoy \& Onbirler, 2017; Ludwig, 2018; Klotz, Calvin, \& Hsu, 2014; Fowowe, 2016; Asaleye, Popoola, Lawal, Ogundipe, \& Ezenwoke, 2018; Asaleye, Isoha, Asamu, Inegbedion, Arisukwu, \& Popoola, 2018; Chen, 2015; Paris, 2018; Bouri, Jalkh, \& Roubaud, 2019). The implication is that shocks to agricultural prices have permanent effects through the stochastic component, and that volatility of commodity prices will increase over time without bound (Kuruppuarachchi, Lin, \& Premachandra, 2017; Jesse Blocher, 2018; Stuart Snaith, 2018).

On the other hand, evidence of stationarity implies that future movement in agricultural commodity prices based on historical evidence is predictable. Under this condition, where commodity prices are predictable, it can be argued empirically that agricultural commodity prices are mean reverting (Brooks, Prokopczuk, Wu, 2015; Alexakis, Bagnarosa, \& Dowling, 2017; Ganneval, 2016; Lawal, Fidelis, Babajide, Obasaju, Oyetade, Lawal-Adedoyin, Ojeka, and Olaniru, 2018; Barbaglia, Wilms, \& Croux, 2016; Biao Guo, 2018; Tse, 2018; Lawal, Somoye, \& Babajide, 2018).

Empirically, a number of research studies have been already conducted to ascertain whether or not agricultural commodity prices follow a random walk process or mean reverting procedures, however, these studies haven't reached any consensus (Beyza Mina Ordu, 2017; Sanders \& Irwin, 2017; Huellen, 2018). These divergent views could be as a result of employment of different estimation techniques, different data size, and diverse economic conditions among others. From the extent literature, a common feature of the studies that examined the unit root property of agricultural commodity prices is that they employed time domain estimation techniques such as serial correlation, Augmented Dickey Fuller test (Fuller, 1979; Perron, 1997; Strazicich \& Lee, 2004), GARCH-based unit root tests such as in (Narayan \& Liu, 2013; Narayan, Sharma, \& Thuraisamy, 2014) among others to examine the existence or otherwise of unit root properties of the series examined. As noted by (Wang, Zhang, \& Zhang, 2015; (Wang \& Mcphail, 2014), time domain unit root test techniques are not appropriate for testing unit root property of high-frequency data series, like daily agricultural commodity prices as they lack the ability to breakdown any ex-post variable on different frequencies when investigating the subtleties of movements across different time horizons without losing information. Besides, time domain techniques lack the capacity to offer a better tradeoff between detecting oscillations and peaks or discontinues. These inadequacies of time domain unit root tests are taken care of by the newly developed econophysics frequency domain wavelet unit root test techniques. These tests' strength lies in its ability to capture the essential characteristics of one or more structural breaks by using just a small number of frequency components from the wavelet approximation (Kumar, Ioan, \& Tiberiu, 2016). This quality is not found in the existing time domain traditional unit root tests. 
Given the advantages of the frequency-based wavelet unit root tests over the existing time domain unit root tests, the current study employed the former to examine whether or not agricultural commodity prices follow a random walk processes or mean reverting procedure. The use of wavelet analysis is important to economic agents as it can, for instance, offer market practitioners the opportunity to analyze their investment horizons in different frequency bonds of scale when making portfolio decisions (Hathroubi \& Aloui, 2016; Bahmani-oskooee, Chang, \& Ranjbar, 2016; Yang, Jing, Zhang, \& Hamori, 2016; Ayopo, Isola, \& Olukayode, 2016a; Jammazi \& Reboredo, 2016; (Martín-barragán, Ramos, \& Veiga, 2015).

As for our results specifically, the evidence abounds to reject the null hypothesis of unit root test when frequency domain wavelet approach is applied to modelling agricultural commodity prices. The current study is further organized as follows. Section two presents the literature review, Section three deals with the methodology, in Section four we present and discuss the results, while section five concludes the study.

\section{LITERATURE REVIEW}

Two theoretical notes govern this study. The first theoretical motivations lies in the Heterogeneous Market Hypothesis $(\mathrm{HMH})$ which stresses that commodity prices are heterogeneous in nature, thus the underlying data generating processes as well as the market microstructure behavior should be examined accordingly. Commodity market is presumed to be more volatile than stock and other financial markets instruments (El \& Arouri, 2011); (Taiwo \& Studies, 2012) ; (El, Arouri, Jouini, \& Khuong, 2011); (Panella, Barcellona, \& Ecclesia, 2012) as it enjoy less trading frequency than stocks, it is characterized by considerable transaction and opportunity cost leading to higher levels of fluctuation with relative low levels of efficiency. The impact of unsystematic factors like weather conditions, political and economic instability, consumer expectations and business fundamentals influences the multi-scale nonlinear features of the market, thus making prediction using conventional time domain estimation techniques that focuses on linearity, autocorrelation, heteroscedasticity unfit to explain the behaviour of agricultural commodity prices (Fam, Hennani, \& Huchet, 2017); (Spencer, Bredin, \& Conlon, 2018); (Boubaker \& Ali, 2017); (Joëts, Mignon, \& Razafindrabe, 2017); (Harvey et al., 2017) (Wang, Wu, \& Yang, 2014); (Babajide, Lawal, \& Somoye, 2015); (Yang, Ce, \& Lian, 2017); (Martín-barragán et al., 2015); (Fatih \& Öcal, 2017)(Salisu et al., 2018). To overcome this challenge, the current study employed a high frequency wavelet based unit root tests techniques.

The second theoretical note that governs this study is the Mean Reverting Hypothesis that states that commodity prices unlike stock prices follows mean reverting processes (1(0) stationary). It explains that due to the inherent features of commodities, unlike stock prices, commodity prices are heterogonous in nature, more volatile and characterized by high level of fluctuation with some level inefficiency. This implies that shocks to commodity prices are temporary, as prices will definitely return to their trend path, thus investors can forecast future fluctuation of commodity prices using past information (Wang \& Mcphail, 2014); (Alzahrani, Masih, \& Al-titi, 2014); (Li, Yao, \& Duchesne, 2014); (Bai et al., 2016); (Boubaker \& Ali, 2017); (Boubaker \& Sghaier, 2015) (Wang et al., 2015); (Wang et al., 2014); (Ftiti, Kablan, \& Guesmi, 2016).

The mean reversion hypothesis is an offshoot of the overreaction hypothesis that stresses that market behaviour is often influenced by the reactions (optimism and pessimism) of investors i.e. irrational behavior of noise traders, presence of asymmetric information, negative serial correlation among others (Wang et al., 2015); (Bouri, Jalkh, et al., 2019); (Joëts et al., 2017); (Nicola, Pace, \& Hernandez, 2016). 
Empirical evidence on the efficiency nature of commodity prices is at best mixed. While some (Harvey et al., 2017); (Bohl et al., 2018) are of the view that commodity prices follows random walk (characterized by a unit root / efficient), others are of the views that commodity prices are inefficient or mean reverting (Ganneval, 2016); (Aït-youcef, 2018).

Irwin and Sanders (2012) examined the behavior of agricultural commodities prices from Master Hypothesis point of view. The study noted that significant changes in term of deviation from the fundamental value, with massive impact of pervasiveness across commodity futures are the key features of agricultural commodity prices. The study suggest that caution should be exercised on policies that attempts to limit speculative positions in the agricultural commodity markets.

Huellen (2018) employed the Markov regime-switching regression analysis to examine the impact of financial investment on agricultural commodity prices with a focus on the US grain market. The study offered a price pressure augmented commodity storage framework that connect the scale of nonconvergence to financial investment window via indices traded on the floor of exchange. The results show that the studied indices are not mean reverting.

Gutierrez (2013) employed a bootstrap estimation techniques and Monte-Carlo simulation model to examine the unit root properties of commodity prices based on data sourced from 1985 to 2010 on rough rice, wheat, corn and soya beans. The study noted existence of explosiveness in the future prices of the series studied excepts for soya beans. A major flaw of the study was that it failed to provide a structural break useful in determining the motivating factors for bubbles in the series studied.

Areal, Balcanbe and Rapsomanikis (2016) employed the generalized Sup augmented Dickey-Fuller (GDADF) techniques to examine the existence of explosive bubbles in the price series of some 28 agricultural commodities prices based on monthly data sourced from 1980 to 2012. The study noted that price bubbles are noticed to occurred in 16 out of the 38 indices studied. The study further noted that bubbles are relatively short lived with maximum period of existence being four (4) months. The study also observed that after the summer of 2008, food prices mainly respond to the key fundamental forces in the market. Though, Areal et al, (2016) provides motivation for the occurrences of bubbles at some certain points, it failed by altering the reliability of the results as the model could not calibrate high frequency data set into its model. Agricultural prices are often in high frequency forms.

For the Pakistani economy, Hira and Mumtaz (2019) employed the Phillips et al (2015) GSADF model to examine the existence of bubbles in the agricultural commodity prices based on monthly data sourced from 2000M1 to 2018M5 on seven agricultural prices indices. The indices are on wheat, rice, sugar, cotton, maize, barley and soy bean. The study observed that bubbles occurs in all the price series with rice having the longest bubble period of 34 months spreading from the year 2006 to 2008. Like existing studies on agricultural prices bubble, the study failed to identify the likely causes of price bubbles from a global socio-economic perspective.

Salisu, Oloko and Isah (2017) employed a battery of traditional unit root tests and the GARCHbased unit root tests proposed by Narayan and Liu (2015) to investigate the existence of bubbles in daily agricultural gain prices based on data sourced from 1986 to 2015. The study reported that daily agricultural gains prices exhibits time trend, structural breaks and conditional heteroscedascity. The study further reveals that the traditional unit root tests (ADF and PP) reported that all the series but Oats are nonstationary. When GARCH-based unit root test was calibrated into the study, it was revealed that the study could not reject the unit null hypothesis for three of the five series studied. The study concluded that shocks to agricultural grains prices are temporary, thus, their past behavior can be used in forecasting their future paths.

Zhang and Qu (2015) examined the impact of shock in the global oil prices on agricultural commodities (with a focus on wheat, corn, soybean, bean pulp, cotton and natural rubber) in China. The 
study treated oil price volatility process as a product of induced continuous and jump processes, and how the processes impact on agricultural commodities. The study noted that shock to most agricultural commodities are asymmetric. The results of both the ARJI-GARCH and the ARMA-GARCH models show that negative shocks to agricultural commodities exhibits stronger impact than positive shocks.

\section{METHODOLOGY}

Data for this study comprises of daily global grain futures for corn, oats, Rough Rice, Soybean \& Wheat sourced from 6 ${ }^{\text {th }}$ of January 1986 to 30 $0^{\text {th }}$ December, 2018 from the Chicago Mercantile Exchange futures Database. The commodity prices are denominated by cents/ bushed with each price series containing 6657 observations. The first order differences of logarithmic daily prices were taken as a proxy of returns while the absolute returns were used as the daily volatilities.

Existing studies on mean reverting essentially focus on the univariate properties of the series by employing traditional unit root test techniques like the ADF, PP, among others. Recent evidence has shown that traditional unit root tests lacks the power to incorporate structural breaks and heteroscedasticity in its analysis, suggesting its inability to detect existence of mean reversion in commodity prices (Perron, 1989); (Salisu, Oloko, \& Isah, 2017); (Salisu \& Adeleke, 2016); (Lawal, Babajide, Nwanji, \& Eluyela, 2018); (Salisu, Swaray, \& Oloko, 2018). It has also been observed that beyond the issues of structural breaks and heteroskedascity, inability to capture the frequency-domain components of series may render results on random walk validity misleading as it has been established in literature that time series data (especially high frequency data) are often driven by frequency drifts rather than time domain scale (wavelet).

Consequently, (Fan \& Gencay, 2010); (Marius, Ihnatov, \& Kumar, 2014)) developed a discrete wavelet transformation (DWT) stationary wavelet unit root test and Morlet wavelet test to examine the stationary behaviour of time series data. The tests strength lies in its ability to capture the essential characteristics of one or more structural breaks by using just a small number of frequency components from the wavelet approximation (Kumar, Ioan, \& Tiberiu, 2016)). The wavelet estimation techniques are presented in the subsequent chapter.

As earlier stated, the current study employed an econophysics wavelet analysis to examine whether or not commodity markets prices follows mean reverting procedure. Application of wavelet unit root test techniques have been employed on a number of time series data like stock market, sovereign bond yield, electricity prices, oil prices among others (Yang et al., 2017); (Monir, Saiti, \& Masih, 2016); (Lawal, Nwanji, Adama \& Otekunrin, 2017). As earlier noted, wavelet among other things is advantageous over the existing unit root test techniques because it can decompose a time series into more elementary functions that contain information on a series time series.

Based on different normalization rules, two types of wavelet can be identified. They are father wavelet and mother wavelet. The former represents the smooth and low frequency parts of signal (i.e. the raw data), while the later represents the detail and the high-frequency components. Wavelet provides good localization characters both at the time and frequency domains. Wavelets can be divided into two types: Continuous wavelets transformation (CW'T) and discrete wavelet transformation (DWT).

For signal y $(\mathrm{t})$, CWT is as follows:

$$
C W T_{y}(\alpha, \tau)=\frac{1}{\sqrt{|\alpha|}} \int_{-\infty}^{+\infty} y(t) \psi^{*}\left(\frac{t-\tau}{\alpha}\right) d t
$$


Here $\alpha$ represents the scale parameter; $\tau$ represent the translation parameter; $\psi^{*}$ represents the complex conjugate function.

The discrete wavelet in presented as follows:

$$
D_{W}(m, n)=\alpha_{0}^{-\frac{m}{2}} \int_{-\infty}^{+\infty} y(t) \psi^{*}\left(\alpha_{0}^{-m_{t}}-n \tau_{0}\right) d t
$$

Here $m$ represent the scaling constant (decomposition level) and $n$ is the translating constant. The DWT employs both the low-pass and high -pass filters in lieu of father and mother wavelets, and allows irregular information to be extracted from the ongoing signal ${ }^{1}$

As noted by (Torrence \& Compo, 1995), Fourier space offers a most convenient way to conduct wavelet transform. The Morlet wavelet can be defined as follows:

$$
\psi(t)=\pi^{-\frac{1}{4}} e^{\omega_{0} t} e^{-\frac{1}{2} t^{2}}
$$

Where $\omega_{0}$ and $t$ represents the dimensionless frequency and time respectively. The Fourier transform that correspond to this wavelet is as stated.

Following (Becker, Enders \& Lee, 2004); ( Carrion-i-Silvestre, J., Kim, D., \& Perron, P. 2009); (Karavias \& Tzavalis, 2014); (Author et al., 2014); (Bahmani-oskooee et al., 2016); (Ferrer, Bolós, \& Benítez, 2016); (Bouri, Chang, \& Gupta, 2017) among others, we modify the wavelet frame work to account for the presence of several smooth breaks with an unknown time. This we do by first considering the following data generating process (DGP):

$$
\widehat{\psi}(\omega)=\pi^{\frac{1}{4}} \sqrt{2} e^{-\frac{1}{2}\left(\omega-\omega_{0}\right)^{2}}
$$

The $r_{t}$ process is defined as presented in equ (5)

$$
r_{t}=r_{t-1}+u_{t}
$$

Here $\omega_{0}$ represents the stationary errors, $t$ represents the independent and identically distributed (i, I, d) with variance $\boldsymbol{\sigma}_{\boldsymbol{\mu}}^{\mathbf{2}}$. The null hypothesis explains that $\boldsymbol{\sigma}_{\boldsymbol{\mu}}^{\mathbf{2}}=0$, thus the process defined in equation 4 and equation 5 is stationary.

Given that the wavelet analysis has the capacity to approximate correctly the integral functions with certain degree of accuracy, we select $\left[\sin \left(\frac{2 \pi k t}{T}\right)\right]$ and $\left[\cos \left(\frac{2 \pi k t}{T}\right)\right]$ here $k$ is the frequency for the approximation while $\gamma=\left[\gamma_{1}, \gamma_{2}\right]$ defines the amplitude and displacement of the frequency component. As noted by (J. Wang et al., 2015), in a situation where $\left[\sin \left(\frac{2 \pi k t}{T}\right)\right]$ and $\left[\cos \left(\frac{2 \pi k t}{T}\right)\right]$ does not exist, the DGP in equations (4) and (5) will corresponds to that of KPSS statistic.

We adjust the equations (4) \& (5) by first obtaining their residuals such that they becomes as stated in (6) and (7) respectively in order to test the null of level stationary and the null of trend stationary.

$$
\begin{aligned}
& y_{t}=\alpha_{0}+\gamma_{1} \sin (2 \pi k t / T)+\gamma_{2} \cos (2 \pi k t / T)+e_{t} \\
& y_{t}=\alpha_{0}+\beta t+\gamma_{1} \sin (2 \pi k t / T)+\gamma_{2} \cos (2 \pi k t / T)+e_{t}
\end{aligned}
$$

The tests statistics are as presented below:

$$
\begin{aligned}
& \tau_{\mu}(k) \text { or } \tau_{\tau}(k)=\frac{1}{T^{2}} \frac{\sum_{t=1}^{T} \tilde{s}_{t}(k)^{2}}{\sigma^{2}} \\
& \tilde{\sigma}^{2}=\tilde{\gamma}_{0}+2 \sum w_{j} \tilde{\gamma}_{j}
\end{aligned}
$$

Here, $\tilde{s}(k)=\sum_{j=1}^{t} \tilde{\mathrm{e}} j$, while $j$ are the OLS residuals obtained from the regression in equation (6) for $\tau_{\mu}(k)$ or Equation $(7)$ for $\tau_{\tau}(k)$.

\footnotetext{
${ }^{1}$ For details on derivation of Wavelet techniques, readers are advised to see ((Mallat, 1989); (Torrence \& Compo, 1995); (Ferrer et
} al., 2016). 
Wavelet is preferred to other time domain techniques because it possess the ability to extract information from time series at various points without losing its timescale dimension. This is key to analyzing high frequency data like daily grain prices, and is not presence in the existing traditional unit root techniques and the GARCH models. More so, it is well established in literature that when we neglect the nonlinearity and / or structural changes components of a data generating process as common with existing traditional unit root tests, chances are high that we will obtain spurious results tending towards accepting the null of a unit root (Lawal, Olayanju, Salisu, Asaleye, Dahunsi, Dada, Omoju, \& Popoola, (2019).

\section{CONDUCTING RESEARCH AND RESULTS}

Table 1 present the results of the descriptive statistics of the variables used in our model. From the results is can be deduced that soybean has the highest average returns, while rice has the lowest average return. All the variables show case similar or identical variances. Soybeans also has the highest standard deviation, while rice has the lowest standard deviation. It can also be seen that each of the variables returns is highly leptokurtic. Negative skewness was recorded in almost all the series studied, suggesting that more extreme losses occurred than extreme gains. The Kurtosis for most of the series are more than 3, suggesting that higher chances of extreme market movement. The results of the Jarque-Bera tests suggest all the series are non - normal.

Table 1

Descriptive Statistics

\begin{tabular}{|c|c|c|c|c|c|}
\hline Series & Mean & $\begin{array}{c}\text { Standard } \\
\text { Deviation }\end{array}$ & Skewness & Kurtosis & Jarque-Bera \\
\hline Corn & 392.879 & 294.211 & -1.392 & 3.921 & $79.8421^{* * *}$ \\
\hline Oats & 342.678 & 278.072 & -1.077 & 3.008 & $134.942^{* * *}$ \\
\hline Rice & 10.594 & 9.462 & -0.726 & 2.841 & $16.3874^{* * *}$ \\
\hline Soybeans & 889.642 & 724.801 & 1.8422 & 4.770 & $371.482^{* * *}$ \\
\hline Wheat & 548.095 & 417.099 & -1.524 & 4.911 & $474.809^{* * *}$ \\
\hline
\end{tabular}

Source: Authors' computations 2019

Having conducted the descriptive analysis we proceeds to conducting the unit root test so as to know whether or not commodity prices follows mean reverting process. First, we conduct our analysis by employing the traditional unit root tests techniques like ADF, PP, and KPSS. The results based on the traditional unit root tests shows that all the series are non -stationary. Our results here are in line with existing studies that employed traditional unit root test to examine the existence or otherwise of stationary in time series data (see for instance (Salisu \& Adeleke, 2016); (Salisu et al., 2017); (Jushan Bai and Pierre Perron, 2003); (Narayan \& Liu, 2013) among others). This implies that commodity prices are efficient and that shock to price movement is permanent. We extend our analysis by calibrating test for heteroscedastic in the model by employing GARCH-based unit root test such as the (Westerlund \& Narayan, 2015) hereafter (W\&N, 2015) and (Narayan, Liu, \& Westerlund, 2016) hereafter N, L \& W, 2016).

The results of the calibrated heteroscedastics model reveal that existence of stationary can be established for corn, oat and wheat. In order words, we reject the null hypothesis of unit root test for these variables when we employed GARCH based unit root test proposed by (Westerlund, J. and Narayan, 2015) and (Narayan, P. K., Liu, R. and Westerlund, 2016). From the results we can equally 
observed that the null unit root cannot be rejected for rice and soybean using GARCH based models2 Our results are in line with that of Gutierrez (2013), Salisu et al (2017), among others.

Table 2

Time Domain Unit Root Test

\begin{tabular}{|c|c|c|c|c|c|}
\hline \multirow{2}{*}{ Series } & \multicolumn{2}{|c|}{ Non- Heteroscedasity Unit root tests } & \multicolumn{2}{c|}{ Heteroscedasity Unit root tests } \\
\cline { 2 - 6 } & ADF & PP & KPSS & N\&W(2015) & N,L\&W(2016) \\
\hline Corn & -2.566 & -2.688 & -2.254 & $-3.644^{*}$ & $-3.069^{*}$ \\
\hline Oats & $-3.144^{*}$ & $-3.255^{*}$ & -3.875 & $-7.0145^{*}$ & $-6.331^{*}$ \\
\hline Rice & -2.889 & -2.807 & $-2.966^{*}$ & -2.077 & -3.055 \\
\hline Soybean & -2.965 & -2.699 & -2.501 & -2.601 & -3.048 \\
\hline Wheat & -3.221 & -3.201 & -3.012 & $-5.652^{*}$ & $-5.669^{*}$ \\
\hline
\end{tabular}

Source: Authors' computation 2019

When we model the series using frequency domain wavelet based unit root test, our results reveals that all the series are stationary. Our results also show that, when frequency domain is factored into commodity prices efficiency framework, evidence abound to support the existence of mean-reverting process for all the selected commodity prices. This implies that the selected soft commodity market prices are inefficient, can accommodate arbitrage opportunity as it offers investors opportunities to predict price movement using historical data based on technical analysis. Our results are in line with that Areal et al, (2016), Fatima and Ahmed (2019). See also (Bahmani-oskooee et al., 2016); (Li et al., 2014); (Jammazi \& Reboredo, 2016); (Yang et al., 2017); (Fernández-macho, 2012); (Boubaker \& Ali, 2017); (Lawal, Nwanji, Adama \& Otekunrin, 2017)

The results of the structural breaks show the existence of heterogeneous structural breaks points (Ti). It is appropriate to question whether or not the break points as presented are realistic or coincide with significant changes in the global political and socio-economic space. We offered some insightful explanations as presented below.

In the year 1996, the US adverse weather condition significantly affects the global output of maize, wheat and soybeans. This led to a corresponding shock in their prices. In a related development, the global food crisis that occurred in the year 2007-2008 had severe effects on corn, wheat and rice produce. These crises also have significant effect on their prices. The date breaks in each of these series coincides with the stated events. In the same vein, the date breaks observed in the 2014-2015 coincides with the global commodity prices downturn that occurred between June 2014 and February 2015. The shocks was a multifactor shock emanating from a series of industry-specific, China's sustainable economic growth, shale-energy boom, macroeconomic and financial factors causing a joint and simultaneous significant drop across a number of commodity prices such that commodity prices drops by about $38 \%$.

The results obtained so far has some significant economic implications. For instance, if commodity price are mean-reverting this implies that shocks to commodity prices are temporary, thus a substantial part of changes in prices is predictable. This further implies that investment in commodity prices is less risky for longer investment horizon. Furthermore, when commodity prices are mean-reverting excess

2 GARCH based unit root test are subjected to a number of conditional variance equation using different lag orders such as GARCH $(1,2)$; GARCH $(2,1)$ and GARCH $(2,2)$. In this study, we observed that the test is not sensitive to lag order of the GARCH model (results of these estimates are available on demand). 
returns can be generated by adopting a contrarian investment strategy which deals with buying past losers or selling past winners.

Table 3

Frequency Domain Unit Root Test

\begin{tabular}{|c|c|c|c|c|}
\hline Series & $\hat{\psi} \mathrm{FT}$ & $\mathrm{T}_{l}$ & Regime Dates & $\hat{\psi} \hat{\mathrm{c}}$ \\
\hline Corn & $12.014^{* * *}$ & 1996 & $08 / 07 / 1996$ & $1.012^{* * *}$ \\
& & 2007 & $05 / 03 / 2007$ & $1.122^{* * *}$ \\
& & 2008 & $14 / 07 / 2008$ & $1.542^{* * *}$ \\
\hline Oats & $10.102^{* * *}$ & 2014 & $13 / 03 / 2014$ & $0.466^{* * *}$ \\
& & 2014 & $11 / 06 / 2014$ & $1.422^{* * *}$ \\
& & 2015 & $29 / 05 / 2015$ & $0.881^{* * *}$ \\
\hline Rice & \multirow{2}{*}{$90^{* * *}$} & 2007 & $09 / 04 / 2007$ & $0.924^{* * *}$ \\
& & 2008 & $04 / 08 / 2008$ & $1.811^{* * *}$ \\
& & 2015 & $13 / 07 / 2015$ & $1.440^{* * *}$ \\
\hline Soybeans & $7.877^{* * *}$ & 1996 & $03 / 06 / 1996$ & $1.187^{* * *}$ \\
& & 2014 & $17 / 03 / 2017$ & $1.442^{* * *}$ \\
\hline Wheat & $10.411^{* * *}$ & 1996 & $01 / 04 / 1996$ & $1.221^{* * *}$ \\
& & 2008 & $04 / 08 / 2008$ & $1.112^{* * *}$ \\
\hline
\end{tabular}

Source: Authors' computation 2019

Our results also contributed to methodological issues in examining the predictability cum efficiency nature of commodity prices. From our analysis, it can be evidently seen that when commodity prices were examined within the context of conventional unit root tests, the tests failed to reject the non -stationary hypothesis for all series leading to a misleading result. When we calibrate heteroscedasity framework into our analysis, our results became mixed with stationary observed in some series. When we model our analysis using frequency domain framework, we find evidence that shows that all the series are stationary. This suggests that for a clear and true picture of the behavior of commodity prices viz-a-viz predictability and efficiency, there is a strong reason for researchers to conduct their analysis within frequency domain framework. The idea is that speculators in the market could adopt the strategy of buying low and selling high with a view of identifying abnormal activities that reverts prices to normal pattern.

Our study is an improvement on the existing studies as we analyze our data using both time and frequency domain estimates. Besides, unlike Gutierrez, 2013; Areal et al, 2016; Sanders and Irwin, 2017 and Huellen, 2018, that did not offer structural break in their studies, the current study provides structural break dates with major events in the global socio-economic space, which are key in identifying the date of bubbles and potential signs or forerunners of commodity price bubbles (Lawal, Olayanju, Salisu, Asaleye, Dahunsi, Dada, Omoju, \& Popoola, (2019).

\section{CONCLUSION}

In this study, we examined the mean reversion hypothesis using the frequency domain wavelet unit root tests and a number of traditional unit root tests as well as heteroscedascity GARCH-based unit root tests for some selected soft commodity prices based on daily data sourced between $6^{\text {th }}$ of January 1986 and 29th December, 2017. The results of the wavelet unit root test suggest that the selected series are mean reverting. The results obtained have some policy implication for various economic agents. For instance, evidence of mean reverting implies that adopting a contrarian investment strategy offers intelligent investors' possibility of making excess returns. It also suggests that shocks to commodity prices are temporary as chances are high that prices will naturally return to equilibrium. Furthermore, since 
commodity prices are stationary, shocks in the commodity prices cannot be transmitted directly to the real sector, thus caution should be applied when using macroeconomics policies in manipulating the economy. Policy makers should focus on promoting policies that will enhance investors' access to market information, thereby encouraging their participation in the market.

The research is not an all-inclusive study, future research can focus on hard commodity prices like gold, oil, diamond among others using other estimation techniques like Fourier analysis among others. However, researchers should put in mind that wavelet techniques perform best when faced with large dataset (Lawal, Olayanju, Salisu, Asaleye, Dahunsi, Dada, Omoju, \& Popoola, (2019).

\section{ACKNOWLEDGEMENT}

The authors are thankful to the Internal Grant Agency of Landmark University No.2017:08CBS/CAS to support this research.

\section{REFERENCES}

Adämmer, P., \& Bohl, M. T. (2015). Speculative bubbles in agricultural prices . The Quarterly Review of Economics and Finance 55 (2015) 67-76.

Ait-youcef, C. (2018). How index investment impacts commodities : A story about the financialization of agricultural commodities. Economic Modelling, (February), 1-11. https://doi.org/10.1016/j.econmod.2018.04.007.

Alexakis, C., Bagnarosa, G., \& Dowling, M. (2017). Do cointegrated commodities bubble together ? the case of hog , corn , and soybean. Finance Research Letters, 23, 96-102. https://doi.org/10.1016/j.frl.2017.02.007.

Alzahrani, M., Masih, M., \& Al-titi, O. (2014). Journal of International Money Linear and non-linear Granger causality between oil spot and futures prices : A wavelet based test, Journal of International Money and Finance 48, 175-201.

Asaleye, A. J., Isoha, L. A., Asamu, F., Inegbedion, H., Arisukwu, O., Popoola, O. (2018). Financial development, manufacturing sector and sustainability: Evidence from Nigeria. Journal of Social Sciences Research, 4(12), 539546.

Asaleye, A. J., Popoola, O., Lawal, A. I., Ogundipe, A. \& Ezenwoke, O. (2018). The credit channels of monetary policy transmission: implications on output and employment in Nigeria. Banks and Bank Systems, 13(4), 103118.

Areal, F.J., Balcome, K., \& Rapsomanikis, G. (2016) Testing for bubbles in agriculture commodity markets. Economía Agrariay Recursos Naturales. 16(1), 59-79.

Ayopo, B. A., Isola, L. A., \& Olukayode, S. R. (2016a). Stock market response to economic growth and interest rate volatility: Evidence from Nigeria. International Journal of Economics and Financial Issues. Retrieved from http://www.scopus.com/inward/record.url?eid=2-s2.0-84979802394\&partnerID=MN8TOARS.

Ayopo, B. A., Isola, L. A., \& Olukayode, S. R. (2016b). Stock market volatility: Does our fundamentals matter? Ikonomicheski Izsledvania. Retrieved from http://www.scopus.com/inward/record.url?eid=2-s2.085010039294\&partnerID=MN8TOARS

Ayopo, B. A., Isola, L. A., \& Olukayode, S. R. (2015). Monetary policy dynamics and the stock market movements: empirical evidence from Nigeria. Journal of Applied Economic Sciences, X38(8), 1179-1188.

Bahmani-oskooee, M., Chang, T., \& Ranjbar, O. (2016). Asymmetric causality using frequency domain and timefrequency domain (wavelet) approaches. Economic Modelling, 56, 66-78. https://doi.org/10.1016/j.econmod.2016.03.002 
Bai, Y., Dong, D., Wu, S., Liu, Z., Zhang, G., \& Xu, K. (2016). A wavelet transformation approach for multi-source gravity fusion: Applications and uncertainty tests. Journal of Applied Geophysics, 128, 18-30. https://doi.org/10.1016/j.jappgeo.2016.03.003

Barbaglia, L., Wilms, I., \& Croux, C. (2016). Commodity dynamics : A sparse multi-class approach. Energy Economics, 60, 62-72. https://doi.org/10.1016/j.eneco.2016.09.013

Becker, R., Enders, W., \& Lee, J. (2004). A general test for time dependence in parameters. Journal of Applied Econometrics, 19, 899-906.

Ordu, B. M., Oran, A. and Soytas U. (2018). Is food financialized? Yes, but only when liquidity is abundant. Journal of Banking and Finance 95, 82-96

Biao Guo, Q. H. and H. L. (2018). Are there gains from using information over the surface of implied volatilities? Journal of Futures Markets, 38(6), 645-672. Retrieved from https:/ / doi.org/10.1002/fut.21903

Bohl, M. T., Siklos, P. L., \& Wellenreuther, C. (2018). Journal of Asian Economics Speculative activity and returns volatility of Chinese agricultural commodity futures. Journal of Asian Economics, 54, 69-91. https://doi.org/10.1016/j.asieco.2017.12.003

Boubaker, H., \& Ali, S. (2017). A wavelet analysis of mean and volatility spillovers between oil and BRICS stock markets, 64, 105-117. https://doi.org/10.1016/j.eneco.2017.01.026

Boubaker, H., \& Sghaier, N. (2015). Semiparametric generalized long-memory modeling of some mena stock market returns: A wavelet approach. Economic Modelling, 50, 254-265. https://doi.org/10.1016/j.econmod.2015.06.027

Bouri, E., Chang, T., \& Gupta, R. (2017). Testing the efficiency of the wine market using unit root tests with sharp and smooth breaks. Wine Economics and Policy, 6, 80-87.

Bouri, E., Jalkh, N., \& Roubaud, D. (2019). Commodity volatility shocks and BRIC sovereign risk: A GARCHquantile approach. Resources Policy, 61, 385-392

Brooks, C., Prokopczuk, M., Wu, Y. (2015). Booms and busts in commodity markets: Market., bubbles or Fundamentals?". Journal of Futures Markets, 35(10), 916-938. Retrieved from http://centaur.reading.ac.uk/39235/

Chen, P. (2015). Global oil prices, macroeconomic fundamentals and China's commodity sector comovements. Energy Policy, 87, 284-294. https://doi.org/10.1016/j.enpol.2015.09.024

Cook, S. (2008). Maximum likelihood unit root test in the presence of GARCH: A new test with increased power. Communication in Statistics-Simulation and Computation, 37(4), 756-765.

Dickey, D. A., Fuller, W. A. (1979). Distribution of the estimators for autoregressive time series with a unit root. Journal of the American Statistical Association, 74, 427-431.

El, M., \& Arouri, H. (2011). Does crude oil move stock markets in Europe? A sector investigation, Economic Modelling 28, 1716-1725

El, M., Arouri, H., Jouini, J., \& Khuong, D. (2011). Journal of International Money Volatility spillovers between oil prices and stock sector returns: Implications for portfolio management, Journal of International Money and Finance 30, 1387-1405

Fam, P. A. P. A. G. U., Hennani, R. A., \& Huchet, N. I. (2017). U. S. monetary policy, commodity prices and the financialization hypothesis. Review of Economic and Business Studies, 10(2), 53-77.

Fan, Y. and Gencay, R. (2010). Unit Root Tests with Wavelets. Econometric Theory, 26, 1305-1331. Retrieved from http://dx.doi.org/10.1017/S0266466609990594 
Fatih, M., \& Öcal, N. (2017). Financial crises and the nature of correlation between commodity and stock markets. International Review of Economics and Finance, 48(August 2014), 56-68. https://doi.org/10.1016/j.iref.2016.11.008

Fernández-macho, J. (2012). Wavelet multiple correlation and cross-correlation: A multiscale analysis of Eurozone stock markets. Physica A, 391(4), 1097-1104. https://doi.org/10.1016/j.physa.2011.11.002

Fernández, A., González, A., \& Rodríguez, D. (2018). Sharing a ride on the commodities roller coaster : Common factors in business cycles of emerging economies \&. Journal of International Economics, 111, 99-121. https://doi.org/10.1016/j.jinteco.2017.11.008

Ferrer, R., Bolós, V. J., \& Benítez, R. (2016). Interest rate changes and stock returns : A European multi-country study with wavelets. International Review of Economics and Finance, 44, 1-12. https://doi.org/10.1016/j.iref.2016.03.001

Fowowe, B. (2016). Do oil prices drive agricultural commodity prices? Evidence from South Africa. Energy, 104, 149-157. https://doi.org/10.1016/j.energy.2016.03.101

Ftiti, Z., Kablan, S., \& Guesmi, K. (2016). What can we learn about commodity and credit cycles ? Evidence from African commodity-exporting countries. Energy Economics, 60, 313-324. https://doi.org/10.1016/j.eneco.2016.10.011

Ganneval, S. (2016). Spatial price transmission on agricultural commodity markets under different volatility regimes, Economic Modelling 52, 173-185

Giampietro, M., Guidolin, M., \& Pedio, M. (2018). Estimating stochastic discount factor models with hidden regimes: Applications to commodity pricing. European Journal of Operational Research, 265(2), 685-702. https://doi.org/10.1016/j.ejor.2017.07.045

Gutierrez, L. (2013). Speculative bubbles in agricultural commodity markets. European Review of Agricultural Economics, $40(2), 217-238$

Harvey, D. I., Kellard, N. M., Madsen, J. B., \& Wohar, M. E. (2017). Long-Run Commodity Prices , Economic Growth, and Interest Rates: 17th Century to the Present Day. World Development, 89, 57-70. https://doi.org/10.1016/j.worlddev.2016.07.012

Hathroubi, S., \& Aloui, C. (2016). On interactions between remittance out fl ows and Saudi Arabian macroeconomy : New evidence from wavelets. Economic Modelling, 59, 32-45. https://doi.org/10.1016/j.econmod.2016.06.018

Hira, F and Mumtaz, A. (2019). Testing for Exuberance Behavior in Agricultural Commodities of Pakistan. MPRA Paper No. 95304, https://mpra.ub.uni-muenchen.de/95304/

Huellen, S. (2018). How financial investment distorts food prices: evidence from U.S. grain markets. Agricultural Economics, 49(2), 171-181

Isola, L. A., Frank, A. and Leke, B. K. (2015). Can Nigeria achieve Millennium Development Goals? Journal of Social Sciences Research, 1(6), 72-78.

Jammazi, R., \& Reboredo, J. C. (2016). Dependence and risk management in oil and stock markets . A waveletcopula analysis. Energy, 107, 866-888. https://doi.org/10.1016/j.energy.2016.02.093

Jawad, S., Shahzad, H., Hernandez, J. A., Al-yahyaee, K. H., \& Jammazi, R. (2018). Asymmetric risk spillovers between oil and agricultural commodities. Energy Policy, 118(August 2017), 182-198. https://doi.org/10.1016/j.enpol.2018.03.074

Jesse Blocher, R. C. and M. M. (2018). Benchmarking commodity investments. Journal of Futures Markets, 38 (3), $340-$ 358. Retrieved from https://doi.org/10.1002/fut.21885 
Joëts, M., Mignon, V., \& Razafindrabe, T. (2017). Does the volatility of commodity prices reflect macroeconomic uncertainty? Energy Economics, 68, 313-326. https://doi.org/10.1016/j.eneco.2017.09.017

Jushan Bai and Pierre Perron. (2003). Computation and analysis of multiple structural change models. Journal of Applied Econometrics, 18(1), 1-22.

Karavias, Y., \& Tzavalis, E. (2014).Testing for unit roots in short panels allowing for a structural break. Computational Statistics and Data Analysis, 76, 391 - 407

Carrion-i-Silvestre, J., Kim, D., \& Perron, P. (2009). GLS-based unit root tests with multiple structural breaks under both the null and the alternative hypotheses. Econometric Theory, 25(6), 1754-1792. doi:10.1017/S0266466609990326

Klotz, P., Calvin, T., \& Hsu, S. (2014). Global commodity prices, economic activity and monetary policy: The relevance of China, Resources Policy 42,1-9

Kumar, A., Ioan, M., \& Tiberiu, C. (2016). Continuous wavelet transform and rolling correlation of European stock markets. International Review of Economics and Finance, 42, 237-256. https://doi.org/10.1016/j.iref.2015.12.002

Kuruppuarachchi, D., Lin, H., \& Premachandra, I. M. (2017). Testing commodity futures market ef fi ciency under time-varying risk premiums and heteroscedastic prices. Economic Modelling, (December), 1-21. https://doi.org/10.1016/j.econmod.2017.12.005

Lawal, A. I., Nwanji, T. I., Oye O. O., Adama, I. J. (2018). Can corporate governance mechanisms deter earnings management? Evidence from firms listed on the Nigerian Stock Exchange. AESTIMATIO, The IEB International Journal of Finance, 17: 220-233

Lawal, A. I., Nwanji T. I, Adama, J. I and Otekunrin, A. O. (2017). Examining the Nigerian stock market efficiency: Empirical evidence from wavelet unit root test approach. Journal of Applied Economic Sciences, 12(6), 52, 16801689.

Lawal, A. I., Oye, O. O., Toro J. \& Fashina, O. A. (2018). Taxation and sustainable economic growth: empirical evidence from Nigeria. In P. P. Sengupta (Ed.), Contemporary Issues on Globalization and Sustainable Development (Volume 1, pp. 121-144). New Delhi: Serials.

Lawal, Adedoyin Isola; Somoye R. O. C., B. A. A. (2018). Are African stock markets efficient? Evidence from wavelet unit root test for random walk. Economics Bulletin, 37(4), 2665-2679.

Lawal, A.I., Fidelis, E. Babajide, A., Obasaju, B., Oyetade, O., Lawal-Adedoyin, B., Ojeka, J. and Olaniru, O. (2018) Impact of Fiscal Policy on Agricultural Output in Nigeria. Journal of Environmental Management and Tourism, (Volume IX, Winter), 7(31): 1428 - 1442. DOI:10.14505/jemt.v9.7(31).08

Lawal, A. I., Olayanju, A., Salisu, A. A., Asaleye,A. J., Dahunsi, O., Dada, O., Omoju, O. E., \& Popoola, O. R. (2019). Examining Rational Bubbles in Oil Prices: Evidence from frequency domain estimates. International Journal of Energy Economics and Policy 9 (2), 166-173

Lawal, A. I., Babajide, A. A., Nwanji, T. I., \& Eluyela, D. (2018). Are Oil Prices Mean Reverting? Evidence from Unit Root Tests with Sharp and Smooth Breaks, International Journal of Energy Economics and Policy 8(6), 292-298.

Lawal, A. I., Nwanji, T. I., Asaleye, A., \& Ahmed, V. (2016). Economic growth, financial development and trade openness in Nigeria: An application of the ARDL bound testing approach. Cogent Economics \& Finance, 4(1), 115. https://doi.org/10.1080/23322039.2016.1258810

Li, L., Yao, S., \& Duchesne, P. (2014). On wavelet-based testing for serial correlation of unknown form using Fan 's adaptive Neyman method, Computational Statistics and Data Analysis 70, 308-327 
Ludwig, M. (2018). Speculation and its impact on liquidity in commodity markets. Resources Policy, (November 2017), 0-1. https://doi.org/10.1016/j.resourpol.2018.05.005

Mallat, G. (1989). A Theory for Multiresolution Signal Decomposition: The Wavelet Representation, II(7).IEEE Transactions on Pattern Analysis and Machine Intelligence 11(7), 674 - 693

Marius, A., Ihnatov, I., \& Kumar, A. (2014). Analyzing time - frequency relationship between interest rate , stock price and exchange rate through continuous wavelet, Economic Modelling 41, 227-238

Martín-barragán, B., Ramos, B., \& Veiga, H. (2015). Correlations between oil and stock markets : A wavelet-based approach, Economic Modelling 50, 212-227.

Monir, A., Saiti, B., \& Masih, M. (2016). The impact of crude oil price on Islamic stock indices of South East Asian countries : Evidence from MGARCH-DCC and wavelet approaches. Borsa_Istanbul Review 16(4), 219 - 232 https://doi.org/10.1016/j.bir.2015.12.002

Narayan, P. K., Liu, R. and Westerlund, J. (2016). (2016). A GARCH model for testing market efficiency. Journal of International Financial Markets, Institutions and Money, 41, 121-138.

Narayan, P. K., Popp, S. (2010). A new unit root test with two structural breaks in level and slope at unknown time. Journal of Applied Statistics, 37(9), 1425-1438.

Narayan, P. K., Sharma, S. S., Thuraisamy, K. T. (2014). An analysis of price discovery from panel data models of CDS and equity returns. Journal of Banking and Finance, 41, 167-177.

Narayan, P. K. and Liu, R. (2011). Are shocks to commodity prices persistent? Applied Energy, 88, 409-416.

Narayan, P. K. and Liu, R. (2013). Determinants of stock price bubbles. Economic Modelling 35, 661-667

Ng, Serena; Perron, P. (2001). Lag length selection and the construction of unit root tests with good size and power. Econometrica; Evanston, 69(6), 1519-1554. Retrieved from https:/ / search.proquest.com/docview/203879633?accountid=160025

Nicola, F. De, Pace, P. De, \& Hernandez, M. A. (2016). Co-movement of major energy, agricultural , and food commodity price returns: A time-series assessment. Energy Economics, 57, 28-41. https://doi.org/10.1016/j.eneco.2016.04.012

Panella, M., Barcellona, F., \& Ecclesia, R. L. D. (2012). Forecasting Energy Commodity Prices Using Neural Networks, Advances in Decision Sciences, Article ID 289810,26pages https://doi.org/10.1155/2012/289810

Paris, A. (2018). On the link between oil and agricultural commodity prices: Do biofuels matter? International Economics, (December 2017), 1-13. https://doi.org/10.1016/j.inteco.2017.12.003

Perron, P. (1989). The great crash, the oil price shock and the unit root hypothesis. Econometrica, 57, 1361-1401.

Perron, P. (1997). Further evidence on breaking trend functions in macroeconomic variables. Journal of Econometrics, $80(2), 355-385$.

Salisu, A. A., \& Adeleke, A. I. (2016). Further application of Narayan and Liu ( 2015 ) unit root model for trending time series. Economic Modelling, 55, 305-314. https://doi.org/10.1016/j.econmod.2016.02.026

Salisu, A. A., Oloko, T. F., \& Isah, K. O. (2017). Are daily agricultural grains prices stationary ? New evidence from GARCH-based unit root tests Centre for Econometric and Allied Research, University of Ibadan Working Papers

Salisu, A. A., Swaray, R., \& Oloko, T. F. (2018). US stocks in the presence of oil price risk : Large cap vs. small cap, Economics and Business Letters 6(4), 116-124. 
Salisu, A. A. \& Tiwari, A. K. \& Raheem, I. D. (2018). Analysing the distribution properties of Bitcoin returns, Working Papers 058, Centre for Econometric and Allied Research, University of Ibadan

Sanders, D. R., \& Irwin, S. H. (2017). Bubbles, Froth and Facts: Another Look at the Masters Hypothesis in Commodity Futures Markets. Journal of Agricultural Economics, 68(2), 345-365. Retrieved from https://doi.org/10.1111/1477-9552.12191

Spencer, S., Bredin, D., \& Conlon, T. (2018). Energy and agricultural commodities revealed through hedging characteristics : Evidence from developing and mature markets. Journal of Commodity Markets, 9(December 2017), 1-20. https://doi.org/10.1016/j.jcomm.2017.12.001

Strazicich, M.C., Lee J., Day, E. (2004). Are countries converging among OECD countries? Time series evidence with two structural break. Journal of Macroeconomics, 26, 131-145.

Stuart Snaith, N. M. K. and N. A. (2018). Open outcry versus electronic trading: Tests of market efficiency on crude palm oil futures. Journal of Futures Markets, 38(6), 673-695. Retrieved from https://doi.org/10.1002/ fut.21899

Taiwo, M., \& Studies, F. (2012). Crude Oil Price, Stock Price and Some Selected Macroeconomic Indicators : Implications on the Growth of Nigeria Economy, Research Journal of Finance and Accounting 3(2), 42-49.

Torrence, C., \& Compo, G. P. (1995). A Practical Guide to Wavelet Analysis. Bulletin of the American Meteorological Society, $79(1), 1-78$

Tse, Y. (2018). Futures, Return predictability and contrarian profits of international index. Journal of Futures Markets, 38(7), 788-803. Retrieved from https://doi.org/10.1002/fut.21892

Ulusoy, V., \& Onbirler, Ö. Ü. (2017). Marginal speculation and hedging in commodity markets. Finance Research Letters, 23, 269-282. https://doi.org/10.1016/j.frl.2017.07.020

Wang, J., Zhang, D., \& Zhang, J. (2015). Mean reversion in stock prices of seven Asian stock markets : Unit root test and stationary test with Fourier functions. International Review of Economics and Finance, 37, 157-164. https://doi.org/10.1016/j.iref.2014.11.020

Wang, S. L., \& Mcphail, L. (2014). Impacts of energy shocks on US agricultural productivity growth and commodity prices - A structural VAR analysis, Energy Economics $46 \quad$ (2014) 435-444 https://doi.org/10.1016/j.eneco.2014.05.006

Wang, Y., Wu, C., \& Yang, L. (2014). Oil price shocks and agricultural commodity prices, Energy Economics 44, 22-35. https://doi.org/10.1016/j.eneco.2014.03.016

Westerlund, J. and Narayan, P. (2015). Testing for predictability in conditional heteroskedastic stock returns. Journal of Financial Economics, 13(2), 342-375.

Yang, L., Jing, X., Zhang, H., \& Hamori, S. (2016). Interdependence of foreign exchange markets : A wavelet coherence analysis. Economic Modelling, 55, 6-14. https://doi.org/10.1016/j.econmod.2016.01.022

Yang, Z., Ce, L., \& Lian, L. (2017). Electricity price forecasting by a hybrid model, combining wavelet transform , ARMA and kernel-based extreme learning machine methods, Applied Energy 190 291-305 https://doi.org/10.1016/j.apenergy.2016.12.130

Zhang, C. \& Qu, X. (2015). The effect of global oil price shocks on China's agricultural commodities. Energy Economics 51 (2015) 354-364

Zivot, E., Andrews, K. (1992). Further evidence on the great crash, the oil price shock, and the unit root hypothesis. Journal of Business and Economic Statistics, 10, 251-270. 